\title{
Marker-Assisted Selection for Resistance to Black Shank Disease in Tobacco
}

\author{
E. S. Johnson, M. F. Wolff, and E. A. Wernsman, Crop Science Department, Campus Box 7620, North Carolina \\ State University, Raleigh, NC 27695-7620; and R. C. Rufty, Dean's Office \& Staff, North Carolina State Univer- \\ sity, Raleigh, NC 27695
}

\begin{abstract}
Johnson, E. S., Wolff, M. F., Wernsman, E. A., and Rufty, R. C. 2002. Marker-assisted selection for resistance to black shank disease in tobacco. Plant Dis. 86:1303-1309.

Bulked segregant (BSA) and random amplified polymorphic DNA (RAPD) analyses were used to identify markers linked to the dominant black shank resistance gene, $P h$, from flue-cured tobacco (Nicotiana tabacum) cv. Coker 371-Gold. Sixty RAPD markers, 54 in coupling and 6 in repulsion phase linkage to $P h$, were identified in a $\mathrm{K}$ 326-derived $\mathrm{BC}_{1} \mathrm{~F}_{1}\left(\mathrm{~K} 326-\mathrm{BC}_{1} \mathrm{~F}_{1}\right)$ doubled haploid (DH) population. Thirty RAPD markers, 26 in coupling and 4 in repulsion phase linkage to $P h$, were used to screen $149 \mathrm{~K} 326-\mathrm{BC}_{2} \mathrm{~F}_{1}$ haploid plants. Complete linkage between the 26 coupling phase markers and $P h$ was confirmed by screening $149 \mathrm{~K} 326-\mathrm{BC}_{2} \mathrm{~F}_{1} \mathrm{DH}$ lines produced from the haploid plants in black shank nurseries. RAPD markers OPZ- $5_{770}$ in coupling and OPZ-7 $7_{370}$ in repulsion phase linkage were used to select plants homozygous for the $P h$ gene for further backcrossing to the widely grown flue-cured cultivar K 326 . Black shank disease nursery evaluation of $11 \mathrm{~K} 326-\mathrm{BC}_{4} \mathrm{~S}_{1}$ lines and their testcross hybrids to a susceptible tester confirmed linkage between $P h$ and OPZ- $5_{770}$. The results demonstrated the efficiency of marker-assisted selection for $P h$ using a RAPD marker linked in coupling and repulsion. Complete linkage between 26 RAPD markers and the $P h$ gene was confirmed in the $\mathrm{K} 326-\mathrm{BC}_{5}$ generation, and RAPD phenotypes were stable across generations and ploidy levels. These RAPD markers are useful in marker-assisted selection for $P h$, an important black shank resistance gene in tobacco.
\end{abstract}

Additional keywords: bulked segregant and RAPD analyses, disease resistance genes, Phytophthora parasitica var. nicotianae

Soilborne oomycete Phytophthora parasitica Dastur var. nicotianae (Breda de Haan) Tucker is the causal agent of tobacco black shank. This disease can devastate both flue-cured and burley tobacco types in many producing areas worldwide and results in millions of dollars in lost revenue annually.

In North Carolina, $P$. parasitica var. nicotianae-infested fields can contain races 0 and 1 of the pathogen; race 0 is more fit and is the predominant pathogenic race (15). Races 2,3 , and isolate 63 of $P$. parasitica var. nicotianae have also been reported to cause black shank in South Africa, Connecticut, and the Hunsur tract in Karnataka, India, respectively $(16,23,25)$. Black shank severity on susceptible genotypes is increased under high stress conditions such as a hot, dry growing season and the presence of root-knot nematodes $(14,20,22)$. An integrated approach involving the use of resistant cultivars, multipurpose soil fumigants, and crop rotation is recommended for control of black shank in flue-cured tobacco (17).

Corresponding author: E. S. Johnson

E-mail: lizzjohnson@ncsu.edu

Accepted for publication 9 July 2002 .

Publication no. D-2002-0927-01R

(C) 2002 The American Phytopathological Society
Host resistance is the most economical form of black shank control. Due to the allopolyploid origin of the species, disease resistance genes from $N$. tabacum sources are under oligogenic control but are simply inherited. Conversely, disease resistance genes of interspecific origin are usually monogenic and express complete dominance in tobacco (29).

Most flue-cured tobacco cultivars possess resistance to black shank conferred by additive genes from cigar tobacco cultivar Florida 301 (Fla 301). These genes confer partial resistance to both races 0 and 1 of $P$. parasitica var. nicotianae $(3,15,28)$. Dominant, monogenic black shank resistance has been transferred to tobacco from Nicotiana plumbaginifolia Viv. and $N$. longiflora Cav. (2,27). Resistance to $P$. parasitica var. nicotianae race 0 in the highly resistant flue-cured cultivar Coker 371-Gold (C 371-G) is controlled by a single dominant gene, $P h$, pyramided upon the Fla 301 system (7).

Space limitations in disease nurseries and variable climatic conditions which influence epidemic development retard progress in breeding for resistance to soilborne pathogens in tobacco. Gametophytic selection for resistance in an $\mathrm{F}_{1}$ Nicotiana africana-derived haploid tobacco population has proven to be a rapid method for developing pure line, black shank resistant genotypes. Segregating haploid populations are screened in disease nurseries, and subsequently the chromosomes are doubled by an in vitro tissue culture procedure to produce doubled haploid (DH) lines. However, selected genotypes can be lost during tissue culture due to the presence of vascular bacterial and fungal endophytes that are not completely controlled with antibiotics (6).

Molecular markers provide a possible solution to this problem. Haploids could be screened for markers, indirectly selected for disease resistance, chromosome doubled, and seed of homozygous lines produced before initiating field trials. In the resulting DH population, genes at the black shank resistance locus would be fixed for the resistance allele, but the gene frequency would be less than one at unselected loci for the rest of the genome. Testing would occur among DH lines in disease nurseries to confirm resistance and eliminate recombinants. Further, the limited space in nurseries could be more efficiently utilized as haploids lacking disease resistance would be eliminated prior to chromosome doubling.

The random amplified polymorphic DNA (RAPD) procedure (31) in combination with bulked segregant analysis (BSA) provides an efficient method for identifying markers linked to specific genes or genomic regions (18). BSA and RAPD analyses have been used in several crop species to identify markers linked to disease resistance genes. The objectives of this study were to identify RAPD markers linked to the $P h$ gene from C 371-G and to assess their utility in marker-assisted selection (MAS) in a backcross breeding program for the development of black shank resistant tobacco cultivars.

\section{MATERIALS AND METHODS}

Plant material. Flue-cured tobacco breeding line NCTG 60 , a DH line produced from the $F_{1}$ of C $371-G \times K 326$ and homozygous for the $P h$ gene, was crossed to $\mathrm{K} 326$. Haploid plants were produced from this $\mathrm{BC}_{1} \mathrm{~F}_{1}$ hybrid by crossing it to $N$. africana (5), their chromosome numbers were doubled by the in vitro leaf midvein culture method (12), and the DH lines were self-pollinated. Seventeen DH lines from the $\mathrm{BC}_{1} \mathrm{~F}_{1}$ hybrid were classified for black shank resistance in replicated black shank nursery trials (6) and used in BSA and RAPD analyses to identify markers linked to the $P h$ gene.

Three $\mathrm{BC}_{1} \mathrm{~F}_{1}$ DH lines, DH92-2770-40, DH92-3397-2, and DH92-3397-13, homozygous for $P h$, were crossed to K 326 . A total of 

screened with RAPD markers identified in the $\mathrm{BC}_{1} \mathrm{~F}_{1}$ population bulks as being linked to the $\mathrm{Ph}$ locus. The chromosomes of each $\mathrm{BC}_{2} \mathrm{~F}_{1}$ ing DH line was self-pollinated and crossed to a black shank susceptible tester, DH94-1577-

1. DH lines and their testcross hybrids were evaluated for black shank resistance in a field disease nursery (Fig. 1).

RAPD markers OPZ-5 $5_{770}$ and OPZ-7 370 linked in coupling and repulsion phase,

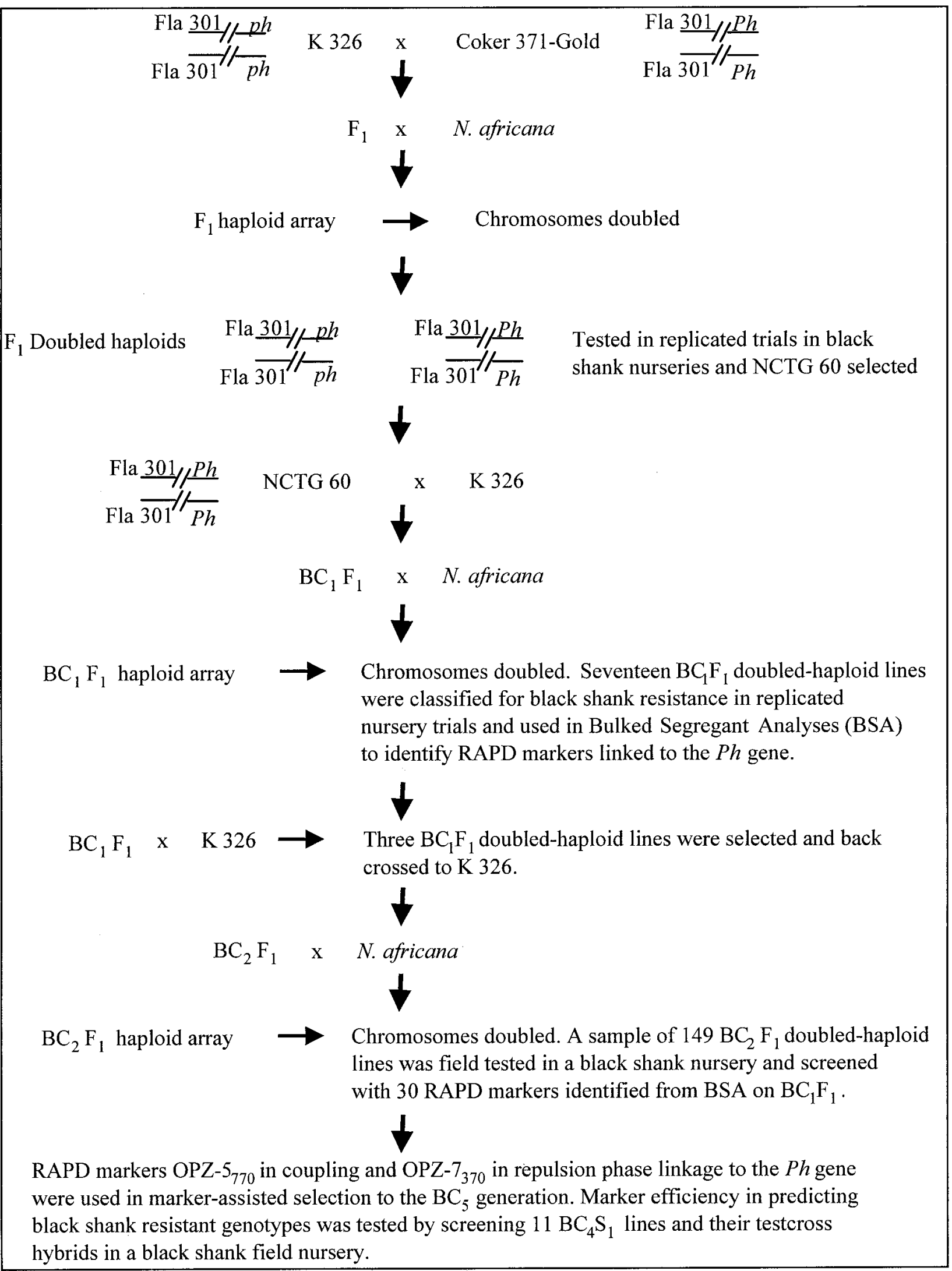

Fig. 1. Flow chart of the production and testing of plant materials used in this study. 
respectively, to the $P h$ gene were used in MAS to the $\mathrm{K} 326-\mathrm{BC}_{5}$ generation. In the $\mathrm{K}$ 326- $\mathrm{BC}_{4} \mathrm{~S}_{1}$ generation, lines were screened with RAPD markers OPZ-5 $5_{770}$ and OPZ-7 370 , and $P h / P h, P h / p h$, and $p h / p h$ genotypes were selected. Each line was self-pollinated and hybridized with black shank susceptible KY 14 to produce testcross hybrids. Eleven $\mathrm{K}$ 326- $\mathrm{BC}_{4} \mathrm{~S}_{1}$ lines and their testcross hybrids were screened in replicated trials in a black shank nursery to determine the precision of RAPD markers OPZ-5770 and OPZ-7 370 in predicting genotypes (Fig. 1).

Black shank disease evaluation in the field and statistical analyses for the $K$ 326- $\mathrm{BC}_{2} \mathrm{~F}_{\mathbf{1}} \mathrm{DH}$ and $\mathrm{K}$ 326- $\mathrm{BC}_{4} \mathrm{~S}_{\mathbf{1}}$ lines. $\mathrm{A}$ sample of $149 \mathrm{~K} 326-\mathrm{BC}_{2} \mathrm{~F}_{1} \mathrm{DH}$ lines and their testcross hybrids were screened in randomized complete block design (RCBD) experiments in black shank nurseries at the Upper Coastal Plain Research Station (UCPRS) in Rocky Mount and the Lower Coastal Plain Tobacco Research Station at Kinston, NC, in 1997. The $11 \mathrm{~K} 326-\mathrm{BC}_{4} \mathrm{~S}_{1}$ lines and their testcross hybrids were screened in an RCBD at the UCPRS in Rocky Mount, NC, in 1998.

In experiments conducted in 1997, each RCBD consisted of 22-plant rows of 25 treatments replicated twice. The treatments consisted of $10 \mathrm{~K} 326-\mathrm{BC}_{2} \mathrm{~F}_{1} \mathrm{DH}$ lines, the $\mathrm{BC}_{1} \mathrm{~F}_{1} \mathrm{DH}$ parent as a resistant check and $\mathrm{K}$ 326 as a susceptible check arranged in a splitplot design with their testcross hybrids and the tester DH94-1577-1 included as another susceptible check. The $10 \mathrm{~K} 326-\mathrm{BC}_{2} \mathrm{~F}_{1} \mathrm{DH}$ lines consisted of an approximately equal mixture of lines having and lacking RAPD markers identified in coupling phase linkage with $P h$ in the $\mathrm{K} 326-\mathrm{BC}_{1} \mathrm{~F}_{1}$ generation. In 1998, the $11 \mathrm{~K} 326-\mathrm{BC}_{4} \mathrm{~S}_{1}$ families and their testcross hybrids were grown in an RCBD experiment with plant row spacing and replications as previously described, with K 326 as the susceptible check.

In tests conducted in both years, all plots were bordered by the black shank susceptible cultivar Hicks to monitor disease pressure and maintain population densities of $P$. parasitica var. nicotianae. Black shank was assessed biweekly on an individual plant basis, with the final disease reading taken 98 days after transplanting. Black shank disease incidence (BSDI) was expressed as a percentage of the number of plants killed by the disease over the total number of plants in that row.

Analyses of variance (ANOVA) were performed on days of survival in the field (DIF) and arcsine transformed percent BSDI data using the GLM procedure in SAS (SAS Institute, Inc., Cary, NC). The data for the $\mathrm{K} 326-\mathrm{BC}_{2} \mathrm{~F}_{1}$ DH lines with RAPD markers linked in coupling phase to the $P h$ locus were analyzed separately from those of the DH lines lacking these markers, to obtain correct $F$ tests for the latter, as the error variance was heterogeneous among the groups.
RAPD analyses of advanced $K$ 326BC lines. All $P h / P h$ homozygous plants identified with RAPD markers OPZ-5 570 and $\mathrm{OPZ}-7_{370}$ in the $\mathrm{K} 326-\mathrm{BC}_{4} \mathrm{~S}_{1}$ population were crossed to $\mathrm{K} 326$ to produce the $\mathrm{BC}_{5}$ generation. Five K $326-\mathrm{BC}_{5}$ plants were screened with 30 RAPD markers (Table 1) to examine linkage relationships of the introgressed region in this advanced generation produced by MAS.

DNA extraction. Total genomic DNA was extracted from leaves 1 to $1.5 \mathrm{~cm}$ long using a modified (11) CTAB method (1). DNA was quantified by fluorometry (Hoefer TKO 100, Pharmacia Biotech, Piscata-

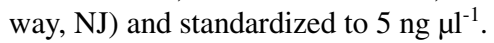

Bulk construction and polymerase chain reaction (PCR) protocols. Two contrasting DNA bulks (18) were formed from equal volumes of standardized DNA from black shank resistant and black shank susceptible $\mathrm{DH}$ lines. Ten $\mathrm{BC}_{1} \mathrm{~F}_{1} \mathrm{DH}$ lines without the $P h$ gene were used to produce a black shank susceptible bulk, and seven $\mathrm{BC}_{1} \mathrm{~F}_{1} \mathrm{DH}$ lines with $P h$ formed a black shank resistant bulk. The bulks were screened with 1,237-decamer primers obtained from Operon Technologies (Alameda, CA) and the University of British Columbia (Vancouver, Canada) to identify polymorphisms between the contrasting bulks.

Each RAPD reaction (31) was performed in a $15-\mu \mathrm{l}$ reaction volume containing $15 \mathrm{ng}$ of genomic DNA, $10 \mathrm{mM}$ Tris$\mathrm{HCl}, \mathrm{pH} 8.3$, and $50 \mathrm{mM} \mathrm{KCl}(1 \times$ Stoffel buffer), $200 \mu \mathrm{M}$ of each dNTP, 1 unit of AmpliTaq DNA polymerase Stoffel fragment (PE Applied Biosystems Corp., Foster City, CA), $4 \mathrm{mM} \mathrm{MgCl}_{2}, 15 \mu \mathrm{g}$ of bovine serum albumin (Sigma Chemical Co.,
St. Louis, MO), and $20 \mathrm{pM}$ of a decamer primer. For a primer control, template DNA was replaced with sterile water (Sigma Chemical Co.). Each reaction was overlaid with $50 \mu \mathrm{l}$ of sterile mineral oil (Sigma Chemical Co.).

Amplifications were performed in a 96well PTC 100 thermal cycler (MJ Research, Watertown, MA); the temperature program used depended on the specific primer (Table 1). Amplified products were separated for $6 \mathrm{~h}$ at $3 \mathrm{~V} / \mathrm{cm}$ constant voltage in $1.5 \%$ cold $\left(4^{\circ} \mathrm{C}\right.$ overnight $)$ agarose gels (Sigma Chemical Co.) containing 0.15 $\mu \mathrm{g}$ of ethidium bromide per liter. Submerged gel electrophoresis was performed in $1 \times$ TBE buffer $(0.09 \mathrm{M}$ Tris borate, $0.002 \mathrm{M}$ EDTA) containing $0.046 \mu \mathrm{g}$ of ethidium bromide per liter. One lane on each gel contained a Lambda EcoRIHindIII marker (Promega, Madison, WI) or a 100-bp DNA Ladder (Gibco BRL, Life Technologies, Grand Island, NY).

\section{RESULTS}

RAPD analyses of the $K$ 326- $B C_{1} F_{1}$ and $\mathrm{K}$ 326- $\mathrm{BC}_{2} \mathrm{~F}_{1} \mathrm{DH}$ lines. A total of 60 easily scored and repeatable RAPD markers, 54 in coupling and 6 in repulsion phase, were identified linked to the $P h$ gene in the $\mathrm{K}$ 326- $\mathrm{BC}_{1} \mathrm{~F}_{1}$ DH lines by BSA and RAPD analyses. A subset of 30 randomly chosen markers, 26 linked in coupling and 4 in repulsion phase (Table 1), was used for estimating linkage distance between the markers and $P h$. Five marker recombination events were observed in the $149 \mathrm{~K} 326-\mathrm{BC}_{2} \mathrm{~F}_{1}$ DH lines analyzed with the 30 markers. Four events occurred in a single $\mathrm{K}$ 326- $\mathrm{BC}_{2} \mathrm{~F}_{1}$ DH line. Two recombination events involved the RAPD

Table 1. Random amplified polymorphic DNA (RAPD) markers in coupling $(\mathrm{n}=26)$ and repulsion phase $(\mathrm{n}=4)$ linkage to the $P h$ gene from tobacco cultivar Coker $371-$ Gold, with their respective amplification programs ${ }^{\mathrm{a}}$

\begin{tabular}{|c|c|c|c|}
\hline RAPD & $\begin{array}{c}\text { Amplification } \\
\text { program }\end{array}$ & RAPD & $\begin{array}{c}\text { Amplification } \\
\text { program }\end{array}$ \\
\hline OPAD- $3_{710}$ & 2 & UBC- $248_{430}$ & 1 \\
\hline OPAJ- $15_{535}$ & 2 & UBC- $265_{1010}$ & 2 \\
\hline OPAJ-12 2525 & 2 & UBC- $30_{490}$ & 1 \\
\hline OPAK-18 645 & 2 & UBC- $333_{270}$ & 1 \\
\hline OPAN-2 260 & 2 & UBC- $422_{420}$ & 2 \\
\hline OPE- $10_{430}$ & $1^{\mathrm{b}}$ & UBC- $427_{575}$ & 2 \\
\hline OPH- $18_{430}$ & $2^{c}$ & UBC- $443_{360}$ & 1 \\
\hline OPM-16 250 & 1 & UBC- $443_{560}$ & 1 \\
\hline OPN-8 $8_{40}$ & $3^{\mathrm{d}}$ & UBC- $469_{385}$ & 2 \\
\hline OPR-1 1160 & 1 & UBC- $564_{345}$ & 2 \\
\hline OPW-3 3410 & 2 & UBC-613 $3_{640}$ & 2 \\
\hline OPZ-5 $5_{770}$ & 1 & OPB-13 $1040^{\mathrm{e}}$ & 2 \\
\hline UBC- $159_{590}$ & 2 & OPZ-7 $370^{\mathrm{e}}$ & 1 \\
\hline UBC-169 680 & 1 & UBC $-365_{565} \mathrm{e}^{\mathrm{e}}$ & 2 \\
\hline UBC- $247_{570}$ & 2 & UBC- $671_{1230}{ }^{\mathrm{e}}$ & 2 \\
\hline
\end{tabular}

${ }^{a}$ RAPD band sizes have a standard deviation of 8 to 16 bp estimated using Seqaid Version 3.8 (Seqaid is available on-line from Indiana University, Bloomington, IN).

${ }^{\text {b }}$ Program 1: 1 cycle $94^{\circ} \mathrm{C} / 30$ s; 3 cycles $94^{\circ} \mathrm{C} / 1 \mathrm{~min}, 38^{\circ} \mathrm{C} / 1 \mathrm{~min}, 72^{\circ} \mathrm{C} / 2 \mathrm{~min} ; 35$ cycles $92^{\circ} \mathrm{C} / 1$ min, $40^{\circ} \mathrm{C} / 1 \mathrm{~min}, 72^{\circ} \mathrm{C} / 2 \mathrm{~min}+1 \mathrm{~s} \mathrm{extension} /$ cycle; 1 cycle $72^{\circ} \mathrm{C} / 5 \mathrm{~min}$.

${ }^{\text {c }}$ Program 2: 1 cycle $94^{\circ} \mathrm{C} / 30 \mathrm{~s} ; 3$ cycles $94^{\circ} \mathrm{C} / 1 \mathrm{~min}, 38^{\circ} \mathrm{C} / 1 \mathrm{~min}, 72^{\circ} \mathrm{C} / 2 \mathrm{~min} ; 35$ cycles $92^{\circ} \mathrm{C} / 10 \mathrm{~s}$, $40^{\circ} \mathrm{C} / 20 \mathrm{~s}, 72^{\circ} \mathrm{C} / 2 \mathrm{~min}+1 \mathrm{~s}$ extension $/$ cycle; 1 cycle $72^{\circ} \mathrm{C} / 5 \mathrm{~min}$.

${ }^{\mathrm{d}}$ Program 3: 1 cycle $94^{\circ} \mathrm{C} / 1 \mathrm{~min} ; 15$ cycles $92^{\circ} \mathrm{C} / 30 \mathrm{~s}, 50^{\circ} \mathrm{C} / 30 \mathrm{~s}-0.5^{\circ} \mathrm{C} /$ cycle, $72^{\circ} \mathrm{C} / 2 \mathrm{~min} ; 20$ cycles $92^{\circ} \mathrm{C} / 10 \mathrm{~s}, 40^{\circ} \mathrm{C} / 20 \mathrm{~s}, 72^{\circ} \mathrm{C} / 2 \mathrm{~min}+1 \mathrm{~s}$ extension/cycle; 1 cycle $72^{\circ} \mathrm{C} / 5 \mathrm{~min}$.

e RAPD markers in repulsion-phase linkage to $P h$. 
OPAK-18 645 . No recombinants were observed for RAPD markers linked in repulsion phase to $P h$. Thus, determination of linkage distance between the 30 RAPD markers and $P h$ was not feasible.

Black shank disease evaluation of $K$ 326- $\mathrm{BC}_{2} \mathrm{~F}_{1} \mathrm{DH}$ lines in the field. Black shank severity was similar at both locations, except for one of the experiments at Kinston. This accounted for most of the variability in disease pressure observed between locations (Table 2). If this experiment with only $35 \%$ BSDI was eliminated, only a $2 \%$ difference in $\%$ BSDI was observed between locations.

Black shank incidence reached $100 \%$ in the susceptible checks within $66 \pm 6$ days after transplanting, indicating high levels of $P$. parasitica var. nicotianae at both locations. Mean DIF was $83 \pm 7$ days, and BSDI was $54 \pm 23 \%$ for the check K 326 , which possesses a low level of partial Fla 301 black shank resistance.

K 326- $\mathrm{BC}_{2} \mathrm{~F}_{1}$ DH lines with $P h$ and their testcross hybrids survived the entire growing season (98 days) at both locations (Table 2). Conversely, $\mathrm{K} 326-\mathrm{BC}_{2} \mathrm{~F}_{1} \mathrm{DH}$ lines, their testcross hybrids, and susceptible checks without $P h$ succumbed to black shank within 75 days of transplanting.

The 30 RAPD markers linked to the $P h$ locus in the $\mathrm{K} 326-\mathrm{BC}_{1} \mathrm{~F}_{1}$ bulks accurately predicted the genotypes of the $149 \mathrm{~K} 326-$ $\mathrm{BC}_{2} \mathrm{~F}_{1} \mathrm{DH}$ lines classified in the haploid state. Mean DIF and BSDI for the K 326$\mathrm{BC}_{2} \mathrm{~F}_{1} \mathrm{DH}$ lines with coupling markers were not significantly different from each other, their testcross hybrids, or the parental lines with $P h$ (Table 2). Mean DIF and BSDI for the $\mathrm{K} 326-\mathrm{BC}_{2} \mathrm{~F}_{1}$ DH lines lacking the coupling markers were significantly different from those of lines with the markers and from the susceptible checks $\mathrm{K}$ 326 and DH94-1577-1 (Table 2).

Genotype identification and disease evaluation of advanced $\mathrm{K}$ 326-BC lines. Disease nursery data for the $\mathrm{K} 326-\mathrm{BC}_{2} \mathrm{~F}_{1}$ DH lines confirmed that $P h$ and the RAPD markers linked to this gene were inherited as a block. Markers OPZ- $5_{770}$ and OPZ$7_{370}$ linked in coupling and repulsion phase, respectively, were used in MAS to produce advanced generations of $\mathrm{K}$ 326$\mathrm{BC}$ populations. Selection of plants with
OPZ-5 770 identified $P h / p h$ heterozygous plants. Selection for OPZ-5 $5_{770}$ and against OPZ-7 370 in the segregating $\mathrm{K} 326-\mathrm{BC}_{4} \mathrm{~S}_{1}$ population identified $\mathrm{Ph} / \mathrm{Ph}$ homozygous plants (Fig. 2).

Weather conditions were conducive to disease development in the black shank nursery at UCPRS in Rocky Mount, NC, in 1998. Mean DIF was 79 days and BSDI was $48 \%$ for the susceptible check K 326 . The mean DIF and BSDI values for K 326 in 1998 were well within one standard deviation of the mean values obtained for this line at this location in 1997. The black shank disease response in the $11 \mathrm{~K}$ 326$\mathrm{BC}_{4} \mathrm{~S}_{1}$ lines selected by MAS with OPZ$5_{770}$ and OPZ- $7_{370}$ was in complete agreement with genotypes predicted by the markers. $P h / P h$ and $P h / p h$ genotypes with RAPD marker OPZ- $5_{770}$ survived the entire growing season in the black shank nursery. The $p h / p h \mathrm{~K} 326-\mathrm{BC}_{4} \mathrm{~S}_{1}$ lines lacking OPZ- $5_{770}$ had a disease response similar to that of the susceptible check $\mathrm{K}$ 326.

Mean DIF and BSDI for $P h / P h$ and $P h / p h$ genotypes were not significantly different, while mean DIF and BSDI for the testcross hybrids of the two genotypic classes were significantly different. Disease responses of the $P h / P h$ and $P h / p h$ genotypes were not significantly different from that of the DH check possessing $P h$. However, disease response of the $P h / P h$ and $P h / p h$ genotypes was significantly different from that of the susceptible check K 326 lacking $P h$, but possessing low, partial Fla 301 resistance (Table 3).

All 30 RAPD markers identified in the $\mathrm{K} 326-\mathrm{BC}_{1} \mathrm{~F}_{1}$ BSA were present in the five $\mathrm{K} 326-\mathrm{BC}_{5}$ plants screened. This indicated that $P h$ was segregating as expected and that no recombination within the chromosomal block had occurred. Three plants were heterozygous for $P h$ and two were homozygous for the susceptible allele (Fig. 2). Banding patterns were similar between the early and advanced K 326-BC generations.

\section{DISCUSSION}

The dominant nature of the $P h$ gene was confirmed in black shank nursery evaluations of the $149 \mathrm{~K} 326-\mathrm{BC}_{2} \mathrm{~F}_{1} \mathrm{DH}$ lines, in that disease responses of the $P h / P h$ homozygous DH lines were indistinguishable from those of their testcross hybrids and parental checks containing the gene. The ANOVA of the disease response showed that the variation in response of $P h / P h \mathrm{~K}$ $326-\mathrm{BC}_{2} \mathrm{~F}_{1} \mathrm{DH}$ lines was due to environmental differences between experiments and not genetic differences among the $P h / P h$ DH lines.

Disease severity in lines lacking the coupling phase markers was variable and ranged from high to low black shank resistance. This varying level of resistance was assumed to be mediated by genes from Fla 301. The evaluation of a testcross hybrid with its parental line negated the need for multiple trials over locations and years in black shank nurseries to differentiate between genotypes possessing high Fla 301 resistance and those having the $P h$ gene. Testcross hybrids of lines with high Fla 301 resistance expressed a lower level of black shank resistance than those of $P h / P h$ DH parental lines.

Twenty-six RAPD markers in coupling and four in repulsion phase linkage to $P h$ were identified in a $\mathrm{K} 326-\mathrm{BC}_{1} \mathrm{~F}_{1} \mathrm{DH}$ population by BSA and RAPD analyses. Banding patterns produced by 28 of the RAPD primers were highly reproducible in all generations tested and in both haploid and diploid states. However, the intensity of RAPD bands for primers UBC-443 and UBC-613 was repeatedly very weak in the diploid $\mathrm{BC}_{5}$ generation compared with the haploid $\mathrm{BC}_{2} \mathrm{~F}_{1}$ generation. It is very unlikely that these observations were due to artifacts of RAPD amplification $(9,13)$, as no major changes in DNA template:primer ratio were made. A possible cause may be a dilution effect or incomplete dominance as a result of competition for RAPD reaction components between alleles at this locus and other loci. If the match between the primer and the binding site at the alternative locus is better than that in the block containing $P h$, then competitive amplification by two copies at the alternative locus in the diploid state could have partially or completely blocked the formation of the expected products from UBC-613 and UBC-443. It was shown that loss of a band in RAPD analyses with a

Table 2. Mean squares and significance levels for days of survival in the field (DIF) and black shank disease incidence (BSDI) in $149 \mathrm{~K}_{3} 26-\mathrm{BC} \mathrm{F}_{2} \mathrm{~F}_{1}$ tobacco doubled haploid (DH) lines and their testcross hybrids in black shank nurseries at Rocky Mount and Kinston, NC, in 1997

\begin{tabular}{|c|c|c|c|c|c|c|}
\hline \multirow[b]{2}{*}{ Source } & \multicolumn{3}{|c|}{ Mean square (lines with coupling markers) } & \multicolumn{3}{|c|}{ Mean square (lines lacking coupling markers) } \\
\hline & df & DIF & BSDI & df & DIF & BSDI \\
\hline Experiment (Expt) & 14 & $6.47 * \mathrm{a}$ & $0.03 * * *$ & 14 & $1,502.1 * * *$ & 1.57 \\
\hline Replication (Expt) & 15 & 2.44 & 0.01 & 15 & $156.6^{* * *}$ & $0.19^{* *}$ \\
\hline Line vs. testcross hybrid & 1 & 0.53 & 0.00 & 1 & $422.5 * * *$ & 0.20 \\
\hline Line within cross & 136 & 3.45 & 0.01 & 163 & $109.1 * * *$ & $0.14 * *$ \\
\hline Error & 151 & 3.68 & 0.01 & 202 & 50.6 & 0.07 \\
\hline $\begin{array}{l}\text { Lines with vs. lines without } \\
\text { coupling markers }\end{array}$ & 1 & $20.26 * * *$ & $1.02 * * *$ & & & \\
\hline Lines vs. DH 94-1577-1 & 1 & $31.66 * * *$ & $1.40 * * *$ & 1 & $11.5^{* * *}$ & $0.38 * *$ \\
\hline Lines vs. K 326 & 1 & $14.51 * * *$ & $0.80^{* * *}$ & 1 & $5.7 *$ & 0.22 \\
\hline
\end{tabular}

a $*, * *, * * *=$ significance at the $0.05,0.01$, and 0.005 probability levels, respectively. 
single primer for eight Xanthomonas campestris strains, with the potential to amplify two bands at unrelated loci, was due to preferred synthesis of one band over the other product (26).

The RAPD markers all appear to be tightly linked in the block containing $P h$ and were useful in MAS of this gene into $\mathrm{K} 326$. Thus, the 30 RAPD markers used in this study were just as informative as all 60 identified. We used OPZ- $5_{770}$ in coupling and $\mathrm{OPZ}-7_{370}$ in repulsion phase linkage to produce advanced K 326 backcross generations possessing $P h$. The success of MAS was confirmed by disease evaluation of the $\mathrm{K} 326-\mathrm{BC}_{4} \mathrm{~S}_{1}$ generation in a black shank nursery. Three backcross generations per year using MAS in greenhouse plantings were possible, compared with one generation per year with $\mathrm{DH}$ production and field testing to identify $P h / P h$ homozygous lines.

The RAPD markers in coupling phase linkage to $P h$ were not present in lines with high Fla 301 resistance. This implies that $P h$ and the genes for the Fla 301 black shank resistance are not in the same linkage group or are more than $50 \mathrm{cM}$ apart.

Marker-assisted selection for $\mathrm{Ph}$ can be used in conjunction with greenhouse evaluations with race 1 of $P$. parasitica var. nicotianae to pyramid black shank resistance to both races of the pathogen (32). Selection for resistance to $P$. parasitica var. nicotianae race 1 in populations heterogeneous for Fla 301 resistance but homozy-

\section{A}

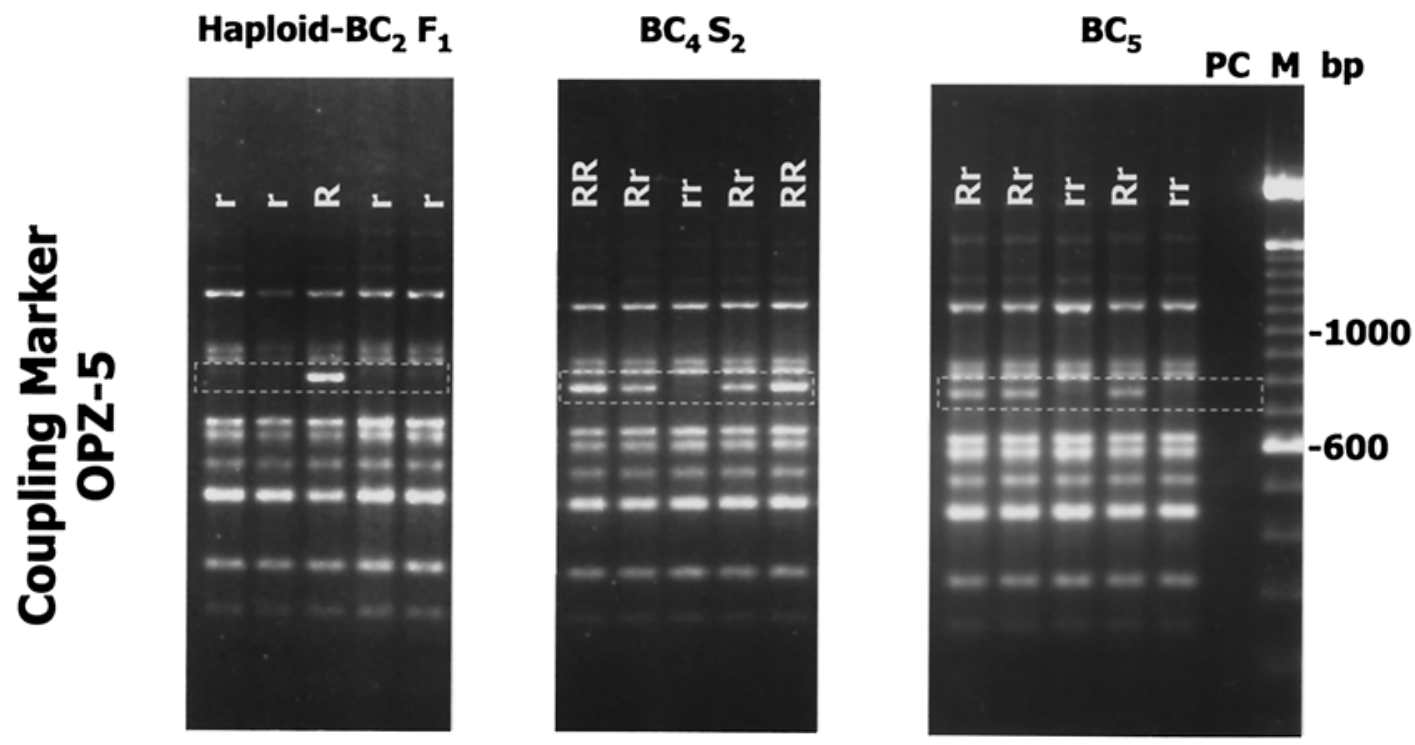

B

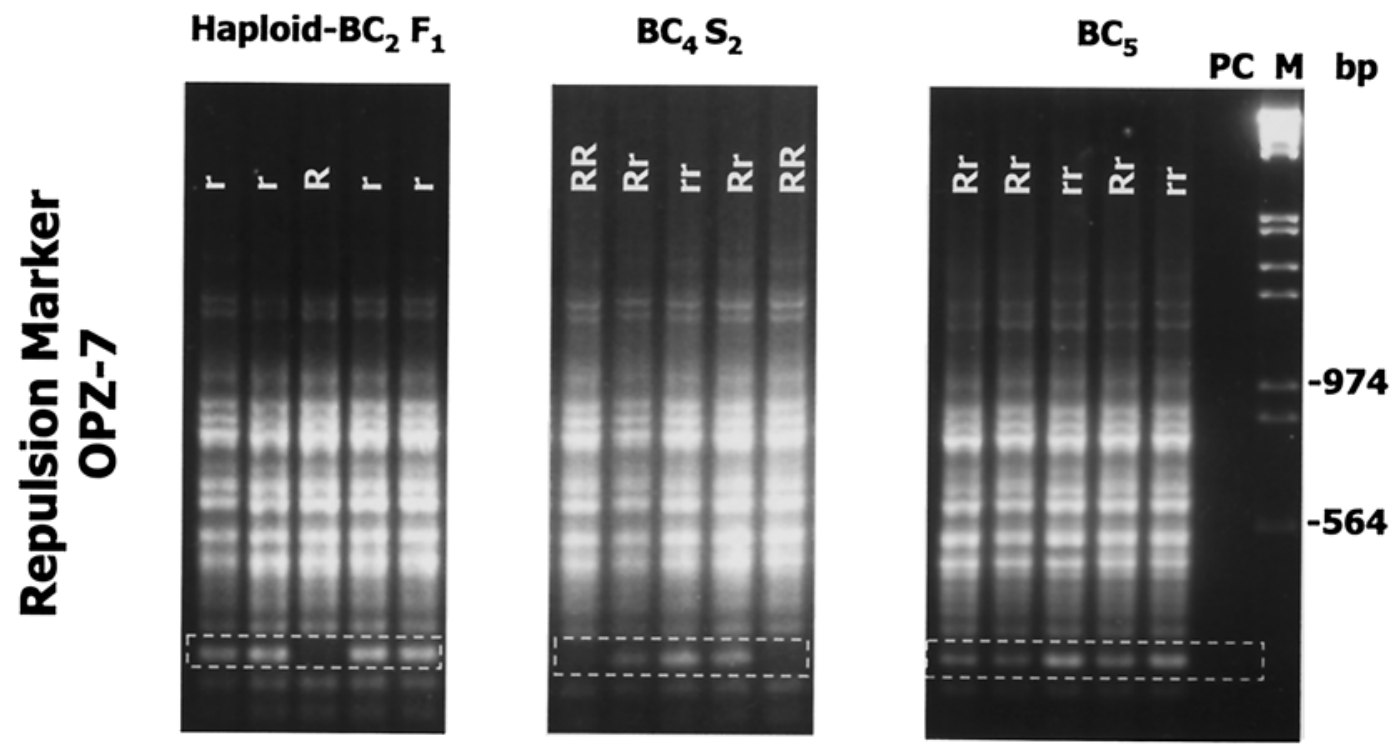

Fig. 2. Amplification products produced by primers OPZ-5 and OPZ-7 in tobacco haploid and diploid K 326-derived backcross generations on a $1.5 \%$ agarose gel. Random amplified polymorphic DNA (RAPD) markers A, OPZ-5 $5_{770}$ and $\mathbf{B}$, OPZ-7 370 , framed by stippling, were identified linked in coupling and repulsion phase, respectively, to the $P h$ gene from Coker $371-$ Gold in the $\mathrm{K} 326-\mathrm{BC}_{1} \mathrm{~F}_{1}$ generation. The RAPD markers accurately identified all $P h$ genotypes in all generations tested in both haploid and diploid plants. The markers were used to select $P h$ heterozygous or homozygous plants for further backcross to K 326. "R" represents the dominant resistant $P h$ allele and " $r$ " the susceptible $p h$ allele. Lane PC is a primer control in which the DNA template was replaced with sterile distilled water. Lane M is either a 100 bp or Lambda EcoRI-HindIII marker. 
Table 3. Mean squares and significance levels for days of survival in the field (DIF) and black shank disease incidence (BSDI) in $11 \mathrm{~K} 326-\mathrm{BC}_{4} \mathrm{~S}_{1}$ tobacco families and their testcross hybrids tested in a black shank nursery at Rocky Mount, NC, in 1998

\begin{tabular}{|c|c|c|c|}
\hline \multirow[b]{2}{*}{ Source } & \multirow[b]{2}{*}{ df } & \multicolumn{2}{|c|}{ Mean square } \\
\hline & & DIF & BSDI \\
\hline Replication & 1 & 4.37 & 0.01 \\
\hline Genotype & 24 & $83.92 *$ a & $0.15^{*}$ \\
\hline Error & 24 & 16.10 & 0.03 \\
\hline $\begin{array}{l}P h / P h \text { vs. } P h / p h \text { genotypes } \\
\text { with OPZ- } 5_{770}\end{array}$ & 1 & 1.20 & 0.11 \\
\hline $\begin{array}{l}P h / P h \text { testcrosses vs. } P h / p h \\
\text { testcrosses }\end{array}$ & 1 & $12.91 * * *$ & $0.51^{* * *}$ \\
\hline $\begin{array}{l}P h / p h \text { with OPZ-5 } \\
\text { vs. checks with } P h\end{array}$ & 1 & 2.32 & 0.18 \\
\hline $\begin{array}{l}P h / p h \text { with OPZ-5 } \\
\text { vs. K } 326 \text { with OPZ-7 } \\
370\end{array}$ & 1 & $11.28 * *$ & $0.59 * * *$ \\
\hline $\begin{array}{l}P h / P h \text { with OPZ- } 5_{770} \\
\text { vs. checks with } P h\end{array}$ & 1 & 1.12 & 0.08 \\
\hline $\begin{array}{l}P h / P h \text { with OPZ-5 } \\
\text { vs. K } 326 \text { with OPZ- } \\
\text { 370 }\end{array}$ & 1 & $12.48 * * *$ & $0.69^{* * *}$ \\
\hline
\end{tabular}

a $*, * *, * * *=$ significance at the $0.05,0.01$, and 0.005 probability levels, respectively.

gous for $P h$ should permit the development of genotypes with very high levels of resistance to both races. Further, screening DH lines or haploid plants with OPZ-5 $5_{770}$ prior to disease evaluation in the black shank nursery would eliminate all genotypes in any generation without $P h$. Thus, space in a disease nursery could be used more efficiently.

Although tight linkage is a prerequisite for successful MAS, the presence of all 26 coupling RAPD markers in the $\mathrm{K}$ 326$\mathrm{BC}_{2} \mathrm{~F}_{1} P h / P h$ DH lines and $\mathrm{K} 326-\mathrm{BC}_{5}$ $\mathrm{Ph} / \mathrm{ph}$ heterozygous plants indicated reduced recombination between the introgressed chromosomal block containing $\mathrm{Ph}$ and its tobacco heterologous segment. Recombination between the markers and $\mathrm{Ph}$ was highly suppressed in the introgressed block, as no recombinants were observed in the $149 \mathrm{~K} 326-\mathrm{BC}_{2} \mathrm{~F}_{1} \mathrm{DH}$ or $11 \mathrm{BC}_{4} \mathrm{~S}_{1}$ lines. The single $\mathrm{K} 326-\mathrm{BC}_{2} \mathrm{~F}_{1}$ $\mathrm{DH}$ line lacking four of the RAPD markers in coupling phase linkage to the $P h$ gene most likely lost a segment of the introgressed block. Thus, the markers may or may not be physically close to the gene.

In cytological studies of substitution lines, a substituted $N$. plumbaginifolia chromosome failed to associate with its $N$. tabacum counterpart during meiosis (10). It was speculated that a similar situation may exist for RAPD markers identified in $N$. tabacum linked to a black root rot resistance gene from $N$. debneyi (4). Low recombination in introgressed regions around interspecific resistance genes has also been reported in tomato and wheat $(8,24,35)$.

Suppressed recombination in regions around an introgressed interspecific resistance gene makes reducing the effect of linkage drag difficult, when it is significant. However, suppressed recombination also facilitates the use of markers to select for multiple disease resistance. In tobacco, marker-assisted selection may be useful in developing cultivars with resistance to black shank, black root rot (4), tobacco wildfire (33), root-knot nematodes (34), blue mold (19), TMV (30), and Potato virus $Y(21)$.

\section{ACKNOWLEDGMENTS}

We gratefully acknowledge Cavell Brownie from the Department of Statistics, North Carolina State University, for statistical consultation. We also thank John Tysinger, Todd Campbell, Lori Linger, Ramsey Lewis, and Susana Milla for assisting with field work and data collection. This work was funded by Philip Morris USA and the North Carolina Tobacco Research Commission.

\section{LITERATURE CITED}

1. Afanador, L. K., Haley, S. D., and Kelly, J. D. 1993. Adoption of a "mini-prep" DNA extraction method for RAPD marker analysis in common bean (Phaseolus vulgaris L). Annu. Rep. Bean Improv. Coop. 36:10-11.

2. Apple, J. L. 1962. Physiological specialization within Phytophthora parasitica var. nicotianae. Phytopathology 52:351-354.

3. Apple, J. L. 1967. Occurrence of race 1 of Phytophthora parasitica var. nicotianae in North Carolina and its importance in breeding for disease resistance. Tob. Sci. 11:79-83.

4. Bai, D., Reeleder, R., and Brandle, J. E. 1995. Identification of two RAPD markers tightly linked with the Nicotiana debneyi gene for resistance to black root rot of tobacco. Theor. Appl. Genet. 91:1184-1189.

5. Burk, L. G., Gerstel, D. U., and Wernsman, E. A. 1979. Maternal haploids of Nicotiana tabacum L. from seed. Science 206:585.

6. Campbell, K. G., and Wernsman, E. A. 1994. Selection among haploid sporophytes for resistance to black shank in tobacco. Crop Sci. 34:662-667.

7. Carlson, S. R., Wolff, M. F., Shew, H. D., and Wernsman, E. A. 1997. Inheritance of resistance to race 0 of Phytophthora parasitica var. nicotianae from the flue-cured tobacco cultivar Coker 371-Gold. Plant Dis. 81:12691274.

8. Chungwongse, J., Bunn, T. B., Crossman, C., Jiang, J., and Tanksley, S. D. 1994. Chromosomal location and molecular marker tagging of powdery mildew resistance gene $(h v)$ in tomato. Theor. Appl. Genet. 89:76-79.

9. Ellsworth, D. L., Rittenhouse, K. D., and Honeycutt, R. L. 1993. Artifactual variation in randomly amplified polymorphic DNA banding patterns. BioTechniques 14:214-217.
10. Gerstel, D. U., and. Burk, L. G. 1960. Controlled introgression in Nicotiana: A cytological study. Tob. Sci. 4:147-150.

11. Johnson, E., Miklas, P. N., Stavely, J. R., and Martinez-Cruzado, J. C. 1995. Coupling- and repulsion-phase RAPDs for marker-assisted selection of PI 181996 rust resistance in common bean. Theor. Appl. Genet. 90:659-664.

12. Kasperbauer, M. J., and Collins, G. B. 1972. Reconstitution of diploids from leaf tissue of anther-derived haploid in tobacco. Crop Sci. 12:98-101.

13. Khandka, D. K., Tuna, M., Tal, M., Nejidat, A., and Golan-Goldhirsh, A. 1997. Variability in the pattern of random amplified polymorphic DNA. Electrophoresis 18:2852-2856.

14. LaMondia, J. A. 1992. Predisposition of broadleaf tobacco to Fusarium wilt by early infection with Globodera tabacum tabacum or Meloidogyne hapla. J. Nematol. 24:425431.

15. Lucas, G. B. 1975. Diseases of Tobacco, 3rd ed. Harold E. Parker and Sons Printers, Fuquay-Varina, NC.

16. McIntyre, J. L., and Taylor, G. S. 1978. Race 3 of Phytophthora parasitica var. nicotianae. Phytopathology 68:35-38.

17. Melton, T. A. 1998. Disease management Pages 92-119 in: 1998 Flue-cured Tobacco Information. North Carolina Cooperative Extension Service, Raleigh.

18. Michelmore, R. W., Paran, I., and Kesseli, R. V. 1991. Identification of markers linked to disease-resistance genes by bulked segregant analysis: A rapid method to detect markers in specific genomic regions by using segregating populations. Proc. Natl. Acad. Sci. USA 88:9828-9832.

19. Milla, S. R. 1998. Identification of RAPD markers linked to blue mold resistance in tobacco. M.S. thesis. North Carolina State University, Raleigh.

20. Moorman, G. W., Huang, J. S., and Powell, N. T. 1980. Localized influence of Meloidogyne incognita on Fusarium wilt resistance of fluecured tobacco. Phytopathology 70:969-970.

21. Noguchi, S., Tajima, T., Yamamoto, Y., and Kubo, T. 1996. Identification of RAPD markers linked to potato virus $\mathrm{Y}$ resistance gene in tobacco. Abstr. P9. CORESTA Inform. Bull. p. 60 .

22. Powell, N. T., and Nusbaum, C. J. 1960. The black shank root-knot complex in flue-cured tobacco. Phytopathology 50:899-906.

23. Prinsloo, G. C., and Pauer, D. C. 1974. Die identikikasie van rasse van Phytophthora nicotianae B de Haan var nicotianae wat in Suid-Afrika voorkom. Phytophylactia 6:217220.

24. Rogowsky, P. M., Guidet, F. L. Y., Langridge, P., Sheperd, K. W., and Koebner, R. M. D. 1991. Isolation and characterization of wheatrye recombinants involving chromosome arm 1DS of wheat. Theor. Appl. Genet. 82:537-544.

25. Shenoi, M. M., Abdul, W. S. M., Elias, N. A., and Bhaktavatsalam, G. 1985. Occurrence of a new race of Phytophthora nicotianae var parasitica in Hunsur tract. Ind. Phytopathol. 38:537-539.

26. Smith, J. J., Scott-Craig, J. S., Leadbetter, J. R., Bush, G. L., Roberts, D. L., and Fulbright, D. W. 1994. Characterization of random amplified polymorphic DNA (RAPD) products from Xanthomonas campestris and some comments on the use of RAPD products in phylogenetic analysis. Mol. Phylogenet. Evol. 3:135-145.

27. Valleau, W. D., Stokes, G. W., and Johnson, E. M. 1960. Nine years' experience with the Nicotiana longiflora factor for resistance to Phytophthora parasitica var nicotianae in the control of black shank. Tob. Sci. 4:92-94.

28. Wernsman, E. A., Matzinger, D. F., and Powell, 
N. T. 1974. Genetic investigations of intraspecific and interspecific sources of black shank resistance in tobacco. Tob. Sci. 18:15-18.

29. Wernsman, E. A., and Rufty, R. C. 1987. Tobacco. Pages 669-698 in: Principles of Cultivar Development, vol. 2. W. R. Fehr, ed. Macmillan Publishing Company, New York.

30. Whitham, S., Dinesh-Kumar, S. P., Choi, D., Hehl, R., Corr, C., and Baker, B. 1994. The product of tobacco mosaic virus resistance gene $N$ : Similarity to toll and interleukin-1 receptor. Cell 78:1101-1115.
31. Williams, J. G. K., Kubelik, A. R., Livak, K. J., Rafalski, J. A., and Tingey, S. V. 1990. DNA polymorphisms amplified by arbitrary primers are useful as genetic markers. Nucleic Acids Res. 18:6531-6535.

32. Wolff, M. F., Johnson, E. S., and Wernsman, E. A. 1998. Consequences of gametic selection for black shank resistance in populations segregating for qualitative and quantitative resistance sources. Abstr. P150. CORESTA Inform. Bull.

33. Yi, Y.-H., Rufty, R. C., and Wernsman, E. A.
1998. Identification of RAPD markers linked to the wildfire resistance gene in tobacco. Tob. Sci. 42:52-57.

34. Yi, Y.-H., Rufty, R. C., Wernsman, E. A., and Conkling, M. C. 1998. Mapping the root-knot nematode resistance gene $(R k)$ in tobacco with RAPD markers. Plant Dis. 82:1319-1322.

35. Young, N. D., and Tanksley, S. D. 1989. RFLP analysis of the size of the chromosomal segments retained around the Tm-2 locus of tomato during backcross breeding. Theor Appl. Genet. 77:353-359. 